\title{
Phytochemical and Toxicological Effect of Ethanol Extract of Heliotropium Indicum on Liver of Male Albino Rats
}

\author{
Babatunde Oluwafemi Adetuyi 1,*iD, Oluwaseun Abraham Adebisi 2, Elukunbi Hilda Awoyelu 1, \\ Oluwatosin Adefunke Adetuyi ${ }^{2}$, Olubanke Olujoke Ogunlana ${ }^{3}$ \\ 1 Department of Natural Sciences, Faculty of Pure and Applied Sciences, Precious Cornerstone University, Ibadan, Oyo \\ State, Nigeria \\ 2 Department of Biochemistry, Faculty of Basic and Applied Sciences, Osun State University, Osogbo, Osun State, Nigeria \\ 3 Department of Biological Sciences (Biochemistry Unit) Covenant University, Ota Ogun State, Nigeria \\ * Correspondence: badetuyi@pcu.edu.ng;
}

(10.09: 10.2020

\begin{abstract}
Heliotropium indicum is a plant of the Boraginaceae family reported to have multiple beneficial health effects, including analgesic, anti-malaria, anti-microbial, anti-tumor, antiinflammatory, amongst others. 42 Male Wistar rats were used for this study. Group A served as control and received distilled water only. Groups B, C, D, E, and F were fed with the extract of Heliotropium Indicum in different concentrations. (500 mg/kg, $1000 \mathrm{mg} / \mathrm{kg}, 1500 \mathrm{mg} / \mathrm{kg} 2000 \mathrm{mg} / \mathrm{kg}$ and 3000 $\mathrm{mg} / \mathrm{kg}$ ) respectively. This study showed that Heliotropium indicum contains phytochemicals such as saponins tannins, cardiac glycosides, and terpenoids. Our results revealed that Heliotropium indicum decreased the ALT, AST, ALP, and bilirubin levels, especially at doses from $1500 \mathrm{mg} / \mathrm{kg} \mathrm{B.W}$. Also, inflammatory cytokine expressions were significantly reduced at similar doses. However, the level of antioxidants (GSH, CAT, GST, SOD, GPx) were significantly increased by Heliotropium indicum administration at doses ranging from $1500 \mathrm{mg} / \mathrm{kg}$ to $3000 \mathrm{mg} / \mathrm{kg}$. The antioxidative potentials of Heliotropium indicum are further complemented by its ability to reduce inflammatory cytokine expression, including TNF- $\alpha$, IL-1 $\beta$, IL- 6, COX-2 as well as NO and LPO. Ethanol extract of Heliotropium indicum at doses between $1500 \mathrm{mg} / \mathrm{kg}$ and $3000 \mathrm{mg} / \mathrm{kg}$ has antioxidative, antiinflammatory effects and can counteract lipid peroxidation.
\end{abstract}

Keywords: Heliotropium indicum; phytochemicals; oxidative stress; inflammation; liverfunction.

(C) 2020 by the authors. This article is an open-access article distributed under the terms and conditions of the Creative Commons Attribution (CC BY) license (https://creativecommons.org/licenses/by/4.0/).

\section{Introduction}

Traditional herbal medicines are normally occurring, plant-sourced substances with next to zero modern handlings that have been utilized to alleviate sickness within conventional healing practices [1,2]. African populaces utilize some type of conventional home grown medication, and the overall yearly market for these items approaches US\$ 60 billion. Nature has given a huge wellspring of therapeutic agents from plants for over a thousand years. A noteworthy number of current medications have been isolated from natural sources. These plants contain several beneficial phytochemicals that potentiate their medicinal activity [3]. High convergences of phytochemicals, which may secure against free radical damage, aggregate in foods grown from the ground [4,5]. Phytochemicals explained explicitly are synthetic substances delivered by plants. Plants containing advantageous phytochemicals may enhance the requirements of the human body by exerting antioxidative capabilities [6]. The 
most significant of these bioactive plant constituents are alkaloids, tannins, flavonoids, and phenolic compounds[5,7].

Helitropium Indicum is a plant identified from the family Boraginaceae, the borage or "forget-me-not" family that is usually shrubs, includes different shrubs, trees, and herbs, making-up about 2,000 species in 146 genera found worldwide. The name "heliotrope" is derived from the idea that plants of this species turn their leaves to the sun [8,9]. It is likewise recognized as a typical weed which develops uncontrollably in crop fields in subtropical and tropical regions of the world. The plant is an annual, erect, branched plant about 15 to $50 \mathrm{~cm}$ high; it is a leafy and a flowering plant [10]. The parts of these plants used medicinally include the whole plant, leaves, flowers, seeds, and the roots. The leaves are utilized for ringworm; the juice is utilized in eye sickness; decoction is utilized in fevers and urticaria. Roots are a love potion; utilized for the fix of night visual deficiency [11].

Heliotropium indicum is accepted to be valuable in treating malaria, stomach agony, and dermatitis. The most elevated number of utilizations (22\%) was accounted for its use against malaria. The mixture of the flower is taken orally for the treatment of menorrhagia in Jamaica [12]. In a concise review by[11], Heliotropium indicum is indicated to have antimicrobial [13], anti-tumour [14,15], anti-inflammatory [16], anti-fertility [12], antituberculosis [17], Analgesic, anti-plasmodial [15] wound healing [18,19], anti-diabetic [20], anti-hepatic and anti-cataract activity [21].

Medicinal plants in traditional clinical practices are as of now not appropriately checked, resulting in an expanded danger of toxicity because of the wrong administration, particularly of those plants that are dangerous at low doses [22]. There is clear proof to implicate oxidative stress as a toxicity mechanism in various tissues. Oxidative stress mirrors a lopsidedness in the degree of body oxidants and its capacity to detoxify them [23]. Oxidative stress has likewise been implicated in several disease conditions, including malignant growth [24], neurodegenerative sicknesses such as Alzheimer's [25], Parkinson's [26], Huntington [27], amyotrophic lateral sclerosis [28], diabetes [29], ulcer [30], among others.

The liver is the major detoxification organ of the body; this is because phase I and phase II transformation pathways occur majorly in the liver. It is known to have significant levels of detoxifying enzymes. These enzymes are largely Cytochrome P450 oxidases (CYPs), UDPglucuronosyltransferases (UGTs), Glutathione S-transferases (GSTs), amongst others [31]. It is worthy of note that the presence of these enzymes also makes the liver a target for oxidativestress induced toxicity[23]. This paper is therefore focused on Heliotropium indicum phytochemical constituents as well as its toxicity in the liver of male Wistar rats.

\section{Materials and Methods}

\subsection{Materials.}

\subsubsection{Animals.}

Albino rats (Rattus norvegicus) weighing between $100.0 \mathrm{~g}$ and $180.0 \mathrm{~g}$ were used in this evaluation. These animals were obtained from Ayoola farmhouse in Ilorin, Kwara State, Nigeria. They were held under standard condition $\left(23 \pm 2^{\circ} \mathrm{C}\right)(55 \pm 10 \%$ humidity $)$ with a $12 \mathrm{~h}$ light/dark cycle. Pellet diet and water were given ad libitum during the course of the experiment. Significantly, the creatures acclimatized to their new environment for about fourteen days before the inception of the experiment. 


\subsubsection{Chemicals.}

Alanine transaminase (ALT), Aspartate transaminase (AST), Alkaline Phosphatase (ALP), and Total Bilirubin were obtained and are products of Randox Laboratories Limited, UK. TNF, COX 2, IL1, and IL 6 ELISA kits were obtained from Cloud-clone Intl Wuhan, China.

\subsubsection{Plant source and identification.}

Heliotropium indicum was obtained from the forest near Ikeji-Arakeji, Osun State. The plants were taken to the Department of Agricultural Sciences, Joseph Ayo Babalola University, for identification.

\subsection{Methods.}

2.2.1. Preparation and extraction of crude plant extract.

Heliotropium indicum leaves were air-dried for three weeks. It was blended into a powdery form using an industrial blender. Exactly $250 \mathrm{~g}$ of the Heliotropium indicum leaf sample was measured with an electronic balance and was soaked in $700 \mathrm{ml}$ of ethanol at room temperature for 48 hours. The solvent was filtered using Whatman filter paper. The extract was stored in the refrigerator until required for use.

\subsubsection{Phytochemical screening of plant extract.}

Basic phytochemical screening is the method employed to test the presence of certain biologically active compounds in plants, e.g., tannins, saponins, anthraquinone, alkaloids, cardiac glycosides, and terpenoid. The methods are as follows [32].

\subsubsection{Test for tannins.}

About $0.2 \mathrm{~g}$ of each portion of plant extract was stirred with $5 \mathrm{ml}$ of distilled water, filtered, and $0.1 \%$ ferric chloride reagent was added to the filtrate. A blue-black green precipitate was taken as evidence for the presence of tannins.

\subsubsection{Test for saponins.}

The capacity of saponins to generate frothing in ethanol solution and to haemolyse red blood cells was used as a screening test for these compounds. For the frothing test, the methods described by each plant extract were shaken with water in a test tube. Frothing which persists on warming was taken as preliminary evidence for the presence of saponins.

\subsubsection{Test for anthraquinone.}

About $0.2 \mathrm{~g}$ of the extract was shaken with $5 \mathrm{ml}$ concentrated benzene, and $5 \mathrm{ml}$ of $10 \%$ $\mathrm{NH}_{3}$ solution was added to the filtrate. The mixture was shaken, and the presence of pink, red, or violet color in the ammonical phase indicates the presence of anthraquinones.

\subsubsection{Test for alkaloids.}

A quantity $\left(1 \mathrm{~cm}^{3}\right)$ of $1 \%$ aqueous $\mathrm{HCl}$ was added to $3 \mathrm{~cm}^{3}$ of each extract in a testtube, and the mixture heated for 20mins, cooled, and filtered. $1 \mathrm{~cm}^{3}$ portion of the filtrate was 
treated with two drops of Wagner's reagent. Formation of cream or brown precipitate respectively indicated the presence of alkaloids

\subsubsection{Test for cardiac glycosides.}

About $1.0 \mathrm{ml}$ of the ethanol extract of the sample plant was added to $2.0 \mathrm{ml}$ of chloroform and shaken. The mixture was allowed to settle down, and $\mathrm{H}_{2} \mathrm{SO}_{4}$ was added carefully to calm the solution. A reddish-brown color at the interface indicates the presence of an aglycone portion of cardiac glycoside.

\subsubsection{Test for terpenoid.}

$1 \mathrm{ml}$ of chloroform was added to $2 \mathrm{ml}$ of each extract, followed by a few drops of concentrated sulphuric acid. A reddish-brown precipitate produced immediately showed the presence of terpenoids.

\subsubsection{Proximate analyses.}

The parameters determined for proximate analyses include ash, moisture, crude protein, fat, fiber, ether extract, and nitrogen-free extract. All of these were carried out using the methods described by [32].

\subsubsection{Animal treatments and Experimental design.}

The experimental animals were divided into six groups of seven animals, each according to their body weight. Group A served as the control and received distilled water only. Groups B to F was fed with the extract of Heliotropium Indicum in different concentrations. (Group B received $500 \mathrm{mg} / \mathrm{kg}$ Heliotropium Indicum, Group C received $1000 \mathrm{mg} / \mathrm{kg}$ Heliotropium Indicum, Group D received $1500 \mathrm{mg} / \mathrm{kg}$ Heliotropium Indicum, Group E received 2000 mg/kg Heliotropium Indicum, Group F received 3000 mg/kg Heliotropium Indicum. At the end of the treatment, the rats were sacrificed, and the liver samples were collected in a clean, dry heparinized bottle, weighed, and homogenized phosphate Buffer solution and used for biochemical tests.

\subsubsection{Determination of oxidative stress and antioxidant indices.}

The liver of each rat was removed, weighed, and washed with ice-cold saline and subsequently homogenized in cold potassium phosphate buffer (0.05 M, pH 7.4). Subsequently, the homogenate was centrifuged at $10,000 \mathrm{~g}$ for $15 \mathrm{~min}$ at $4^{\circ} \mathrm{C}$, and the supernatant was used for the determination of oxidant/antioxidant markers. Protein concentration was determined according to the method of Bradford et al. [33] using bovine serum albumin as standard. Catalase (CAT) activity was determined using $\mathrm{H}_{2} \mathrm{O}_{2}$ as a substrate according to the method described by Clairborne [34]. The inhibition of the autoxidation of epinephrine was used to determine the activity of superoxide dismutase using the method of Misra and Fridovich [35] GSH was evaluated according to the method described by Jollow et al. [36]. Glutathione S-transferase activity was determined according to the method of Habig et al. [37]. Glutathione peroxidase activity was quantified according to the method of Rotruck et al. [38]. Lipid peroxidation was determined as malondialdehyde levels (MDA).

2.2.6. Concentrations of pro-inflammatory biomarkers. 
Liver nitrites content as stable end-products of $\mathrm{NO}$ was obtained using a sodium nitrite curve as standard and expressed as micromolar of nitrites per milligram of protein according to the method described by Green et al. [39]. TNFa, IL 1, IL6, and COX 2 were carried out according to the standard operative procedure of the respective assays.

\subsubsection{Statistical Analysis.}

All results were presented as mean \pm Standard Deviation (SD). Data were analyzed by using Microsoft Excel 2007 (Redmond, Washington, USA) and Graph Pad Prism 6 software (Graph Pad Software Inc., USA). All the information on treatment groups was analyzed and compared with the control group by utilizing one-way ANOVA accompanied by Dunnett's multiple comparison tests. In all the groups, differences were considered statistically significant among groups when $\mathrm{p}<0.05$.

\section{Results and Discussion}

\subsection{Results.}

\subsubsection{Phytochemical Screening.}

The table below shows the result of the phytochemical screening of ethanol extract of Heliotropium indicum leaf.

Table 1. Results of phytochemical screening.

\begin{tabular}{l|l|l} 
S/N & Phytochemical components & Heliotropium indicum ethanol extract \\
\hline 1. & Tannin & + \\
\hline 2. & Saponin & + \\
\hline 3. & Anthraquinone & - \\
\hline 4. & Alkaloids & + \\
\hline 5. & Cardiac Glycoside & - \\
\hline 6. & Terpenoid & + \\
$+=$ present &
\end{tabular}

\subsubsection{Proximate Analysis.}

The table below shows the result obtained for the proximate analysis of dried leaf of Heliotropium indicum.

Table 2.Proximate analysis of dried leaf of Heliotropium indicum.

\begin{tabular}{l} 
Plant Sample \\
\hline H. indicum
\end{tabular}

\subsubsection{Result of body weight.}

The table shows the weight of rats used for the experiment before the treatment and after the treatment with ethanol extract of Heliotropium indicum.

Table 3. Bodyweight change induced by Heliotropium indicum.

\begin{tabular}{l|l|l|l} 
Groups & Body weight $(\mathbf{g})$ & \% Change \\
\hline Group A (Control) & Final & Initial & 0.22 \\
\hline Group B $(500 \mathrm{mg} / \mathrm{Kg})$ & $145.42 \pm 1.46$ & $145.20 \pm 1.67$ & 0.70 \\
\hline Group C $(1000 \mathrm{mg} / \mathrm{Kg})$ & $142.52 \pm 4.01$ & $141.82 \pm 2.93$ & 1.01
\end{tabular}




\begin{tabular}{l|l|c|l} 
Groups & Body weight $(\mathbf{g})$ \\
\hline Group D $(1500 \mathrm{mg} / \mathrm{Kg})$ & $180.05 \pm 1.65$ & $178.76 \pm 1.34$ & 1.29 \\
\hline Group E $(2000 \mathrm{mg} / \mathrm{Kg})$ & $117.36 \pm 1.05$ & $116.35 \pm 2.41$ & 1.01 \\
\hline Group F $(3000 \mathrm{mg} / \mathrm{Kg})$ & $148.94 \pm 3.02$ & $147.56 \pm 3.75$ & 1.38
\end{tabular}

3.1.4. Heliotropium indicum elevated liver function enzymes and bilirubin levels.

A

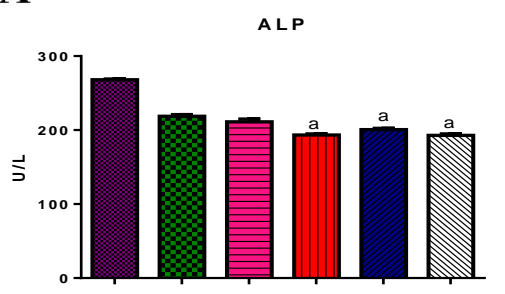

C

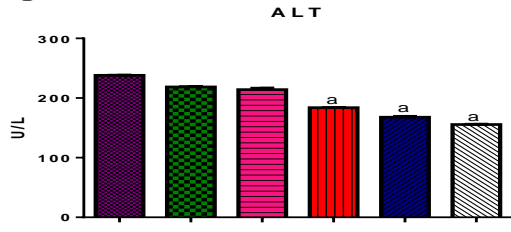

B AST

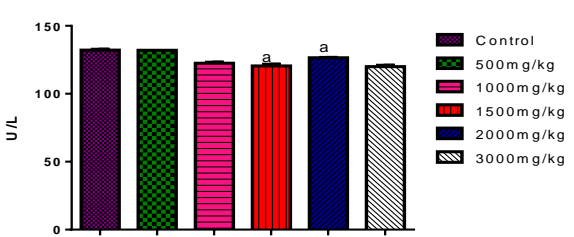

D

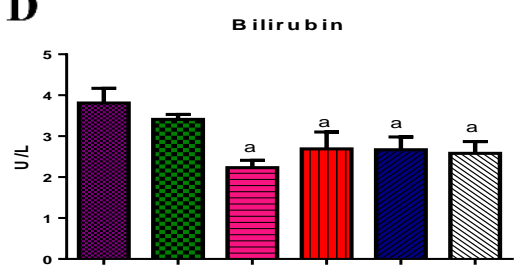

Figure 1.Heliotropium indicum effect on liver function A) ALP B) AST C) ALT and D) BIL. Results are represented as mean $\pm S D, n=5$. a- Significantly different from control $(p<0.05)$.

The effect of Heliotropium indicum on liver function enzymes was investigated. Results from figure 1 showed that liver function enzymes (ALT, AST, and ALP) and bilirubin are significantly decreased from doses from $1500 \mathrm{mg} / \mathrm{kg}$ and above $(\mathrm{p}<0.05)$; however, doses below $1500 \mathrm{mg} / \mathrm{kg}$ were not significantly elevated.
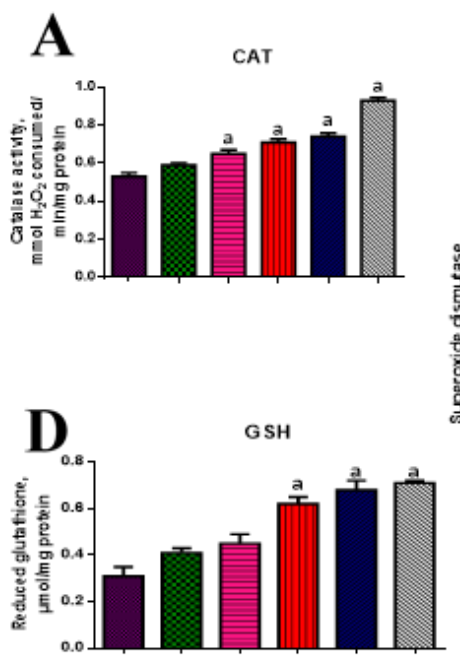
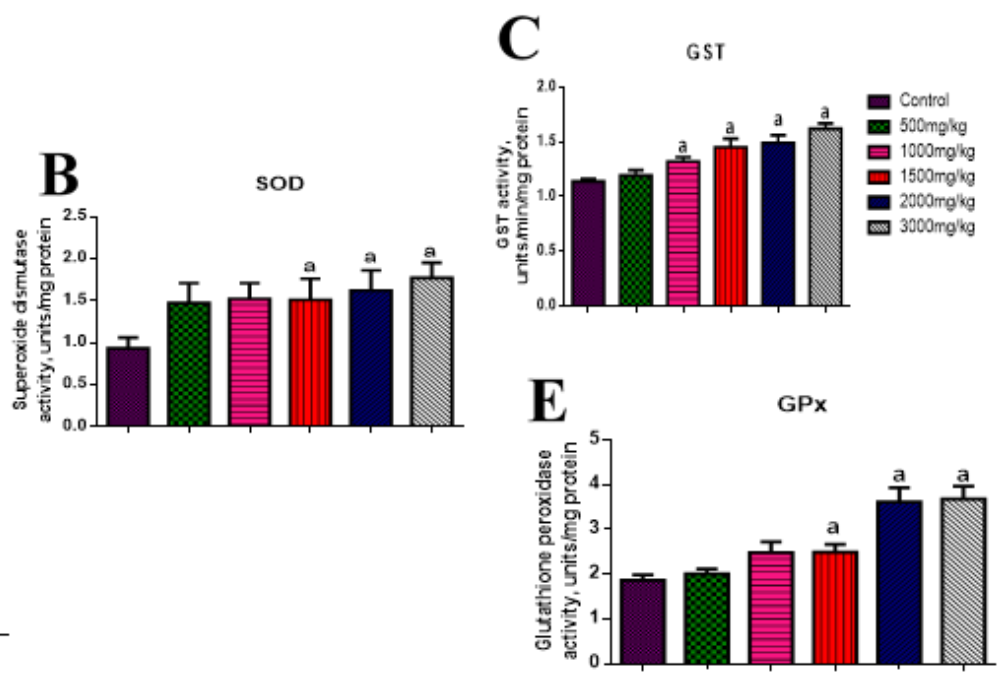

Figure 2. Heliotropium indicum effect on enzymatic and non-enzymatic antioxidants A) CAT B) SOD C) GST D) GSH E) GPx. Results are represented as mean $\pm \mathrm{SD}, \mathrm{n}=5$. a- Significantly different from control $(\mathrm{p}<0.05)$.

3.1.4.Heliotropium indicum elevated levels of enzymatic and non-enzymatic antioxidants.

The effect of Heliotropium indicum on enzymatic and non-enzymatic antioxidants was investigated. Figure 2 shows a significant increase in antioxidant enzymes (CAT, SOD, GST, GPx) and Glutathione, especially at doses higher than $1500 \mathrm{mg} / \mathrm{kg}(\mathrm{p}<0.05)$; however, doses below $1500 \mathrm{mg} / \mathrm{kg}$ were not significantly elevated. 
3.1.5.Heliotropium indicum reduced Lipid peroxidation and Inflammatory Markers.

Heliotropium indicum effect on lipid peroxidation and inflammatory markers were assessed. Figure 3 shows a significant decrease in lipid peroxidation at all doses of Heliotropium indicum. Inflammatory markers levels, including TNF- $\alpha$, COX-2, IL-1 $\beta$, IL-6, and NO, was also significantly decreased, especially at doses from $1500 \mathrm{mg} / \mathrm{kg}(\mathrm{p}<0.05)$.
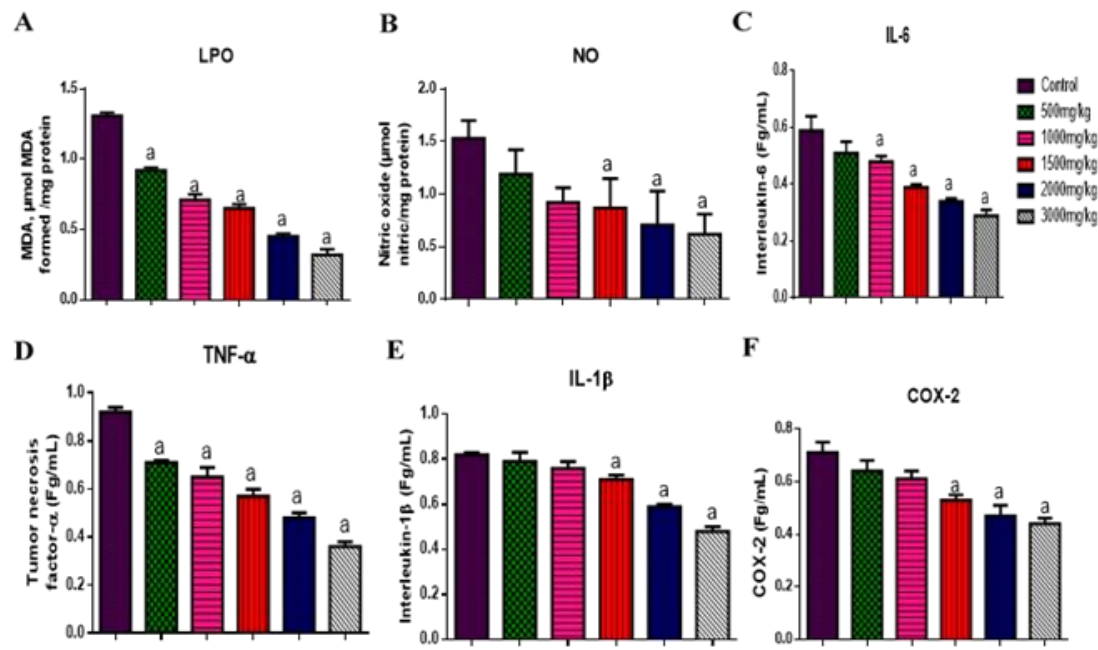

Figure 3.Heliotropium indicum on Lipid peroxidation and Inflammatory markers A) LPO B) NO C) IL-6 D) TNF- $\alpha$ E) IL-1 $\beta$ F) COX-2. Results are represented as mean \pm SD, $n=5$. a- Significantly different from control $(\mathrm{p}<0.05)$

\subsection{Discussion.}

Medicinal plants are important contributors to the pharmaceutical, agricultural, and food industries [40,41]. WHO [42] defines herbal medicines as normally occurring, plantsourced substances with next to zero modern handlings that have been utilized to alleviate sickness within conventional healing practices. Heliotropium indicum is a medicinal plant whose beneficial effects have been shown by various researchers. Results from table 1 showed that Heliotropium indicum is rich in phytochemicals, including saponins, alkaloids, tannins, and terpenoids but anthraquinones and cardiac glycosides are absent in the leaf extract of this plant. These results correlate with that of Basak et al. [43], who reported that Heliotropium indicum ethanol extract contained alkaloids, saponins, flavonoids, amongst others. The presence of these phytochemicals may be indicative of its numerous beneficial health effects that have been reported by several studies. Proximate analysis of the extract showed significant carbohydrate content and fiber content but lowered protein and fat content. Also, the moisture content of the extract is higher than the ash content. Santhosha et al. [44] also reported that ethanol extract of Heliotropium indicum is rich in phenols and flavonoids, although this was not shown by our study. The results of this study show that it increases body weight even when administered at doses as high as $3000 \mathrm{mg} / \mathrm{kg}$

The liver is the major detoxification organ of the body; its ability to detoxify many substances is attributable to the detoxification enzymes it contains; therefore, it is a significant organ in the body [31]. Results from figure 1 showed that liver function enzymes (ALT, AST, and ALP) and bilirubin are significantly decreased from doses from $1500 \mathrm{mg} / \mathrm{kg}$ and above. The aminotransferases, specifically AST and ALT, are refrained to the periportal hepatocytes, where they play a central role in transamination reactions during amino acid metabolism. The 
marked increase in the level of transaminases is indicative of liver injury; this is as shown in lead-induced toxicity [45]. A significant decrease in these enzymes shows that Heliotropium indicum can reduce toxicity in the liver, thereby conferring protective effects on the liver. These results correlate with the study of Owolabi et al. [46] conducted a 5-month study on Heliotropium indicum extract, however, on Sprague-Dawley rats. They demonstrated that the lethal dose (LD50) of Heliotropium indicum is about $508.78 \mathrm{~g} / \mathrm{kg}$, which is higher than all doses used in this study.

Oxidative stress is summarily explained as a lopsidedness in the level of antioxidant enzymes in the body and reactive species the body is exposed to. Oxidative stress is responsible for a host of disease conditions, including cancer and neurodegenerative diseases. An antioxidant is any molecule which in low quantities and in the presence of an oxidizable species, can mitigate the activities of reactive oxygen species. Figure 2 shows a significant increase in antioxidant enzymes (CAT, SOD, GST, GPx) and Glutathione, especially at doses higher than $1500 \mathrm{mg} / \mathrm{kg}$. These enzymes help to maintain redox balance in the system. Their activity can be used to estimate the oxidative defense mechanism strength. [47]. Glutathione is an excellent antioxidant that helps to balance the redox state of the system. GSH is an essential cellular component of the antioxidant defense mechanism that can function as a direct or indirect free-radical scavenger [48]. SOD, CAT, and GPx remove ROS, such as superoxide free radicals, by converting them to water and molecular oxygen. The elevated levels of glutathione and other antioxidant enzymes in the liver would likely have hepatoprotective effects.

Lipid peroxidation and inflammation are markers of toxicity [49]. Lipid peroxidation, as accessed by malondialdehyde (MDA) formation in this study (Figure 3), is significantly reduced by all doses of Heliotropium indicum. This implied that the consumption of this medicinal plant reduced the amount of lipid peroxidation products in the liver of Wistar rats. Cytokines are little secreted proteins $(<40 \mathrm{kDa})$, which are created by almost all cells to control and impact immune reactions [50]. The secretion of pro-inflammatory cytokines will prompt immune cell activation and production with concurrent further cytokines release [51]. Figure 3 shows a significant decrease in inflammatory markers, including TNF- $\alpha$, COX-2, IL-1 $\beta$, IL-6, and NO. All doses of Heliotropium indicum significantly reduced the levels of TNF- $\alpha$. TNF- $\alpha$ mediates cell survival and pro-inflammatory response by TNFR-I via NF- $\kappa B$ and activator protein (AP)-1[52]. Additionally, TNF- $\alpha$ instigates signaling pathways of cell apoptosis via Fas and Caspases. This indicates that Heliotropium indicum may downregulate cell-death and inflammation via TNF- $\alpha$ decreased expression.

The essential IL-1 $\beta$ sources are hematopoietic cells like macrophages, monocytes, including dendritic cells, and microglia or Kupffer cells [53]. IL-1 $\beta$ is a prototypic proinflammatory cytokine that has pleiotropic impacts on different cells and assumes key functions in acute and chronic inflammatory and autoimmune disorders [54]. Figure 3C and $3 \mathrm{E}$ reveal that IL-1 $\beta$ and IL-6 expressions are significantly reduced at doses from $1500 \mathrm{mg} / \mathrm{kg}$ and above. This indicates that Heliotropium indicum may downregulate inflammation via interleukin mediation.

\section{Conclusions}

Ethanol extract of Heliotropium indicum at doses between $1500 \mathrm{mg} / \mathrm{kg}$ and $3000 \mathrm{mg} / \mathrm{kg}$ has antioxidative, anti-inflammatory effects and can counteract lipid peroxidation. Heliotropium indicum can be said to be hepatoprotective at these doses. 


\section{Funding}

This research received no external funding.

\section{Acknowledgments}

This research has no acknowledgment.

\section{Conflicts of Interest}

The authors declare no conflict of interest.

\section{References}

1. World Health Organization WHO global report on traditional and complementary medicine. 2019.

2. Tilburt, J.C.; Kaptchuk, T.J. Herbal medicine research and global health: An ethical analysis. Bull. World Health Organ.2008, 86, 594-599, https://doi.org/10.2471/BLT.07.042820.

3. Nicoletti, M. New solutions using natural products. Insect-Borne Dis. 21st Century2020, 2020, 263-351, https://doi.org/10.1016/b978-0-12-818706-7.00007-3.

4. Suffredini, I.B.; Sader, H.S.; Gonçalves, A.G.; Reis, A.O.; Gales, A.C.; Varella, A.D.; Younes, R.N. Screening of antibacterial extracts from plants native to the Brazilian Amazon Rain Forest and Atlantic Forest. Brazilian J. Med. Biol. Res.2004, 37, 379-384, https://doi.org/10.1590/S0100-879X2004000300015.

5. Altemimi, A.; Lakhssassi, N.; Baharlouei, A.; Watson, D.G.; Lightfoot, D.A. Phytochemicals: Extraction, isolation, and identification of bioactive compounds from plant extracts. Plants2017, 6, https://doi.org/10.3390/plants6040042.

6. Stefanos, L.; Prodromos, S.; Georgia, S. Potential use of Medicinal Plants as Biological Crop Protection Agents. Biomed J Sci Tech Res2020, 25, 1-5, http://dx.doi.org/10.26717/BJSTR.2020.25.004231.

7. Larayetan, R.; Ololade, Z.S.; Ogunmola, O.O.; Ladokun, A. Phytochemical Constituents, Antioxidant, Cytotoxicity, Antimicrobial, Antitrypanosomal, and Antimalarial Potentials of the Crude Extracts of Callistemon citrinus. Evidence-based Complement. Altern. Med.2019, 2019, https://doi.org/10.1155/2019/5410923.

8. Zihad, S.M.N.K.; Gupt, Y.; Uddin, S.J.; Islam, M.T.; Alam, M.R.; Aziz, S.; Hossain, M.; Shilpi, J.A.; Nahar, L.; Sarker, S.D. Nutritional value, micronutrient and antioxidant capacity of some green leafy vegetables commonly used by southern coastal people of Bangladesh. Heliyon 2019, 5, https://doi.org/10.1016/j.heliyon.2019.e02768.

9. Selvi, F.; Bigazzi, M. Leaf surface and anatomy in Boraginaceae tribe Boragineae with respect to ecology and taxonomy. Flora2001, 196, 269-285, https://doi.org/10.1016/S0367-2530(17)30056-7.

10. Ghosh, P.; Das, P.; Das, C.; Mahapatra, S. Morphological Characteristics and Phyto-pharmacological Detailing of Morphological Characteristics and Phyto- pharmacological Detailing of Hatishur (Heliotropium indicum Linn.): A Concise Review. J. Pharmacogn. Phytochem.2018, 7, 1900-1907.

11. Roy, A. Pharmacological Activities of Indian Heliotrope ( Heliotropium Indicum L .): A Review. 2015, 4 , 101-104.

12. Dash, G.K.; Abdullah, M.S. A review on heliotropium indicum L. (Boraginaceae).Int. J. Pharm. Sci. Res.2013.

13. Rao, P.R.; Nammi, S.; Raju, A.D.V. Studies on the Antimicrobial Activity of Heliotropium indicum Linn. J. Nat. Remedies2002, 2, 195-198.

14. Sivajothi, V.; Shruthi, S.D.; Jasmin Sajini, R. Cytotoxic effect of Heliotropium indicum extracts on hela cell line. Int. J. Pharm. Pharm. Sci.2015.

15. Goyal, N.; Sharma, S.K. Bioactive phytoconstituents and plant extracts from genus Heliotropium. Int. J. Green Pharm.2014, 8 .

16. Betanabhatla, K.S.; Jasmin Sajni, R.; Karthik, R.; Raamamurthy, J.; Christina, A.J.M.; Sasikumar, S. Antiinflammatory and anti-nociceptive activities of Heliotropium indicum Linn. in experimental animal models. Pharmacologyonline2007, 3, 438-445.

17. Machan, T.; Korth, J.; Liawruangrath, B.; Liawruangrath, S.; Pyne, S.G. Composition and antituberculosis activity of the volatile oil of Heliotropium indicum Linn. growing in Phitsanulok, Thailand. Flavour Fragr. J.2006, https://doi.org/10.1002/ffj.1577.

18. Reddy, J.S.; Rao, P.R.; Reddy, M.S. Wound healing effects of Heliotropium indicum, Plumbago zeylanicum and Acalypha indica in rats. J. Ethnopharmacol.2002,79, 249-251,https://doi.org/10.1016/S03788741(01)00388-9. 
19. Yeo, D.; Attioua, B.; Lehalle, C.; Kossi, M.; Jean David, N.g.; Djaman, J.; Lobstein, A.; Frossard, N. Isolation of wound healing compounds from Heliotropium indicum. Journal of Applied Pharmaceutical Science 2011, 1, 102-106.

20. Sifat, N.; Zihad, S.M.N.K.; Lovely, F.; Rouf, R.; Shajib, G.M. Al; Alam, M.A.; Shilpi, J.A.; Uddin, S.J. Supplementation of Heliotropium indicum Linn attenuates obesity and associated metabolic disorders in high-carbohydrate-high-fat diet-induced obese rats. J. Food Biochem.2020, 1-12, https://doi.org/10.1111/jfbc.13444.

21. Kumar, S.; Vijaya, V.T.; Kumar, S.S. Anticataract Activity Of Ethanolic Extract Of Heliotropium Indicum Leaveson Galactose Induced In Rats. Int. J. Pharmacol. Toxicol.2015.

22. Fennell, C.W.; Lindsey, K.L.; McGaw, L.J.; Sparg, S.G.; Stafford, G.I.; Elgorashi, E.E.; Grace, O.M.; Van Staden, J. Assessing African medicinal plants for efficacy and safety: Pharmacological screening and toxicology. J. Ethnopharmacol.2004, 94, 205-17, https://doi.org/10.1016/j.jep.2004.05.012.

23. Ore, A.; Akinloye, O.A. Oxidative stress and antioxidant biomarkers in clinical and experimental models of non-alcoholic fatty liver disease. Med.2019, 55, 1-13, https://doi.org/10.3390/medicina55020026.

24. Hayes, J.D.; Dinkova-Kostova, A.T.; Tew, K.D. Oxidative Stress in Cancer. Cancer Cell2020, 38, 167-197, https://doi.org/10.1016/j.ccell.2020.06.001.

25. Cioffi, F.; Adam, R.H.I.; Broersen, K. Molecular Mechanisms and Genetics of Oxidative Stress in Alzheimer's Disease. J. Alzheimer's Dis.2019, 72, 981-1017, https://doi.org/10.3233/JAD-190863.

26. Hemmati-Dinarvand, M.; Saedi, S.; Valilo, M.; Kalantary-Charvadeh, A.; Alizadeh Sani, M.; Kargar, R.; Safari, H.; Samadi, N. Oxidative stress and Parkinson's disease: conflict of oxidant-antioxidant systems. Neurosci. Lett.2019, 709, https://doi.org/10.1016/j.neulet.2019.134296.

27. Zheng, J.; Winderickx, J.; Franssens, V.; Liu, B. A Mitochondria-Associated Oxidative Stress Perspective on Huntington's Disease. Front. Mol. Neurosci.2018, 11, https://doi.org/10.3389/fnmol.2018.00329.

28. Carrera-Juliá, S.; Moreno, M.L.; Barrios, C.; de la Rubia Ortí, J.E.; Drehmer, E. Antioxidant Alternatives in the Treatment of Amyotrophic Lateral Sclerosis: A Comprehensive Review. Front. Physiol.2020, 11, 1-30, https://doi.org/10.3389/fphys.2020.00063.

29. Ma, X.; Chen, Z.; Wang, L.; Wang, G.; Wang, Z.; Dong, X.; Wen, B.; Zhang, Z. The Pathogenesis of Diabetes Mellitus by Oxidative Stress and Inflammation: Its Inhibition by Berberine. Front. Pharmacol.2018, https://doi.org/10.3389/fphar.2018.00782.

30. Sun, G.; Lian, T.; Yang, B.; Gu, Y.; Li, X. Ameliorative effect of Sargassum fusiforme polysaccharides on oxidative stress and inflammation in ethanol-induced gastric ulcer. Pharmacogn. Mag.2019, 15, 244-252, https://doi.org/10.4103/pm.pm_457_18.

31. Tabrez, S.; Ahmad, M. Some enzymatic/non-enzymatic antioxidants as potential stress biomarkers of trichloroethylene, heavy metal mixture, and ethyl alcohol in rat tissues. Environ. Toxicol.2011, 26, 207-216, https://doi.org/10.1002/tox.20548.

32. AOAC Association of Official Analytical Chemists. Official methods of Analysis (Vol.II 17 th edition) of AOAC International. Washington, DC, USA. BioResources 2016.

33. Bradford, M.M. A rapid and sensitive method for the quantitation of microgram quantities of protein utilizing the principle of protein-dye binding. Anal. Biochem. 1976, 72, 248-254, https://doi.org/10.1016/00032697(76)90527-3.

34. Claiborne, A. Catalase activity. In: Hand Book of Methods for Oxygen Radical Research. Greenwald, R.A. (Ed.), CRC Press, Boca Raton, Florida; 1985.

35. Misra, H.P.; Fridovich, I. The role of superoxide anion in the autoxidation of epinephrine and a simple assay for superoxide dismutase. J. Biol. Chem.1972, 247, 3170-3175.

36. Jollow, D.; Mitchell, J.R.; Zampaglione, N.; Gillette, J.R. Bromobenzene-induced liver necrosis. Protective role of glutathione and evidence for 3,4-bromobenzene oxide as the hepatotoxic metabolite. Pharmacology1974, 11, 151-169, https://doi.org/10.1159/000136485.

37. Habig, W.H.; Pabst, M.J.; Jakoby, W.B. Glutathione S transferases. The first enzymatic step in mercapturic acid formation. J. Biol. Chem.1974, 249, 7130-7139.

38. Rotruck, J.T.; Pope, A.L.; Ganther, H.E.; Swanson, A.B.; Hafeman, D.G.; Hoekstra, W.G. Selenium: Biochemical role as a component of glatathione peroxidase. Science (80-.).1973, 179, 588-590, https://doi.org/10.1126/science.179.4073.588.

39. Green, L.C.; Wagner, D.A.; Glogowski, J.; Skipper, P.L.; Wishnok, J.S.; Tannenbaum, S.R. Analysis of nitrate, nitrite, and [15N]nitrate in biological fluids. Anal. Biochem.1982, 126, 131-138, https://doi.org/10.1016/0003-2697(82)90118-X.

40. Godswill Chinaza, A. Medicinal plants: The medical, food and nutritional biochemistry and uses. Int. J. Adv. Acad. Res. Sci. Technol. Eng.2019, 5, 220-241.

41. Hao, D.; Xiao, P. Pharmaceutical resource discovery from traditional medicinal plants: Pharmacophylogeny and pharmacophylogenomics. Chinese Herb. Med.2020, 12, 104-117, https://doi.org/10.1016/j.chmed.2020.03.002.

42. World Health Organization WHO Monographs on Selected Medicinal Plants-Volume 2. WHO Monogr. Sel. Med. Plants 2002. 
43. Basak, M.; Dey, B. Phytochemical and antipyretic potential of ethanolic leaf extract of Heliotropium indicum L. J. Appl. Pharm. Res. 2016.

44. Dasarapu, S.; Alluri, R.; Emandi, H.; Malothu, N. Phyto Chemical Screening And Anti- Oxidant Activity Of Ethanolic Extract Of Heliotropium Indicum. Int. Res. J. Pharm.2015, https://doi.org/10.7897/22308407.068112.

45. El-Nekeety, A.A.; El-Kady, A.A.; Soliman, M.S.; Hassan, N.S.; Abdel-Wahhab, M.A. Protective effect of Aquilegia vulgaris (L.) against lead acetate-induced oxidative stress in rats. Food Chem. Toxicol.2009, 47, 2209-2215, https://doi.org/10.1016/j.fct.2009.06.019.

46. Owolabi, M.A.; Oribayo, O.O.; Ukpo, G.E.; Mbaka, G.O.; Akindehin, O.E. A 5-month toxicity study of the ethanol extract of the leaves of Heliotropium indicum in Sprague Dawley rats after oral administration. Nig. Q. J. Hosp. Med.2015, 25, 184-192.

47. Gutteridge, J.M.C.; Halliwell, B. Antioxidants: Molecules, medicines, and myths. Biochem. Biophys. Res. Commun.2010, 393, 561-4, https://doi.org/10.1016/j.bbrc.2010.02.071.

48. Romão, P.R.T.; Tovar, J.; Fonseca, S.G.; Moraes, R.H.; Cruz, A.K.; Hothersall, J.S.; Noronha-Dutra, A.A.; Ferreira, S.H.; Cunha, F.Q. Glutathione and the redox control system trypanothione/trypanothione reductase are involved in the protection of Leishmania spp. against nitrosothiol-induced cytotoxicity. Brazilian J. Med. Biol. Res.2006, 39, 355-363, https://doi.org/10.1590/S0100-879X2006000300006.

49. Morales, M.; Munné-Bosch, S. Malondialdehyde: Facts and artifacts. Plant Physiol.2019, 180, 1246-1250, https://doi.org/10.1104/pp.19.00405.

50. Akira, S.; Uematsu, S.; Takeuchi, O. Pathogen recognition and innate immunity. Cell2006, 124, 783-801, https://doi.org/10.1016/j.cell.2006.02.015.

51. Schaper, F.; Rose-John, S. Interleukin-6: Biology, signaling and strategies of blockade. Cytokine Growth Factor Rev.2015, 26, 475-487.

52. Bradley, J.R. TNF-mediated inflammatory disease. J. Pathol.2008, 214, 149-160, https://doi.org/10.1002/path.2287.

53. Guilliams, M.; Mildner, A.; Yona, S. Developmental and Functional Heterogeneity of Monocytes. Immunity2018, 49, 595-613, https://doi.org/10.1016/j.immuni.2018.10.005.

54. Ren, K.; Torres, R. Role of interleukin-1 $\beta$ during pain and inflammation. Brain Res. Rev.2009, 60, 57-64, https://doi.org/10.1016/j.brainresrev.2008.12.020. 